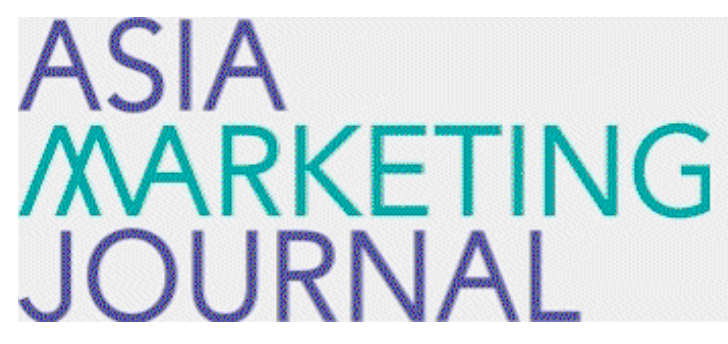

ASIA MARKETING JOURNAL

Volume 15 | Issue 3

Article 7

10-30-2013

\title{
The Mediating Role of Brand Recall and Brand Attitude in Influencing Purchase Intention in Advergames
}

Azaze Azizi Abdul Adis

Hyung Jun Kim

Follow this and additional works at: https://amj.kma.re.kr/journal

Part of the Marketing Commons

\section{Recommended Citation}

Adis, Azaze Azizi Abdul and Kim, Hyung Jun (2013) "The Mediating Role of Brand Recall and Brand Attitude in Influencing Purchase Intention in Advergames," Asia Marketing Journal: Vol. 15 : Iss. 3 , Article 7.

Available at: https://doi.org/10.53728/2765-6500.1561

This Article is brought to you for free and open access by Asia Marketing Journal. It has been accepted for inclusion in Asia Marketing Journal by an authorized editor of Asia Marketing Journal. 


\title{
The Mediating Role of Brand Recall and Brand Attitude in Influencing Purchase Intention in Advergames*
}

\author{
Azaze-Azizi Abdul Adis** \\ Hyung Jun Kim***
}

Research on purchase intention had showed remarkable progress in contributing to the theory of consumer behavior. Despite the popularity of academic discussions on various issues influencing purchase intention, the mediating role of brand recall and brand attitude on purchase intention, in particular advergames, has not yet been well explored, especially in developing economies such as Malaysia. Furthermore, the influence of self-brand congruity, entertainment and brand placement acceptance as antecedents to brand recall and brand attitude are expected to add value to the brand recall, brand attitude and purchase intention relationships.

This paper aims to investigate the impact of the mediating role of brand recall and brand attitude on purchase intention in advergames among Malaysian gamers. The antecedents towards brand recall and brand attitude are also examined to measure their influence on purchase intention. A total of 350 Malaysian gamers were interviewed through online survey in this study. The results showed that brand recall and brand attitude mediate the relationship between self-brand congruity, entertainment and brand placement acceptance with purchase intention. Also, entertainment and brand placement acceptance were found to have a significant relationship with brand recall. As expected, brand recall and brand attitude showed a positive relationship with consumer purchase intention in advergames.

It was found that self-brand congruity has a significant influence on brand attitude and purchase intention. When users see the brand which matches with them, they tend to act positively toward the brand exposed in the game. This is consistent with Escalas and Bettman (2005) who suggested that the greater the congruity, the more positive the consumer's attitude toward the brand in question. This leads to game usage and purchase (Davis and Lang, 2013).

In the advergaming context, the entertainment value in advergames is very important to determine the level of enjoyment and pleasure experienced by gamers during game-playing. Therefore, the more

* This research was done in the College of Business Administration and Economics, Chungnam National University with sponsorship from Universiti Malaysia Sabah.

** Doctoral Candidate of Marketing, College of Business Administration and Eoonomics, Chungnam National University, and Lecturer of Marketing, School of Business and Economics, Universiti Malaysia Sabah. Malaysia (azizi@ums.edu.my)

*** Professor of Marketing. College of Business Administration and Economics, Chungnam National University. Korea (bizguru@cnu.ac.kr), Corresponding Author 
entertaining the ads, the more it will be remembered and the greater the positive behavior of the consumer towards the advergames - this ultimately stimulates their intention to purchase the brand.

This study shows the effect of brand placement on brand recall and brand attitude and also purchase intention. Brand placements might not work in games due to the interactivity involved in game-playing as people could be distracted from noticing the brand placements (Yang et al., 2006). However, the significant influence of brand placements found in this study may provide major promise for advertisers. Game players may or may not explicitly remember the brands they see in the games, but these placements may influence their brand recall and brand attitude and could therefore influence later decisions (Yang et al., 2006).

In this study, it was found that self-brand congruity was not significantly related with brand recall. The reason for this could be attributed to the fact that this study examined gamers who are highly involved in the interactive medium of games which force them to focus on game play rather than advertisements: the level of recognition to remember the brand exposed in the game is low and contributes to the "mismatch" between the gamers and the said brand.

The present study contributes to the existing literature of the antecedents of brand recall and brand attitude in advergames. This study contributes to the role of brand recall and brand attitude as mediators in purchase behavior theory. Academically, the relationship between brand recall and brand attitude is well known in advergaming research, but their impact as important mediators on purchase intention add new understanding in the interactive communication literature. Their mediating role may provide new insights on how they facilitate the effects of self-brand congruity, entertainment and brand placement on purchase intention. Besides that, the studies on the influence of self-brand congruity on brand recall and brand attitude and also consumer intention to purchase had not well-investigated in advergames. This study contributes to fill those gaps in advergames literature.

For practitioners, this study could suggest the use of illustrative or demonstrative placements of new products to help customers remember new brands, and the use of associative placements for existing products to increase consumers' purchase intention (Ho et al., 2011). To advertisers, this study may provide useful information to improve their current advertising strategies in games, for instance, by considering game players' congruity, entertainment value and brand placement factors.

Key words: Brand recall, brand attitude, self-brand congruity, entertainment, brand placement acceptance, purchase intention, advergames 


\section{Introduction}

Advergames is a new marketing concept that has appeared due to the fact that the younger generation is always connected to the Internet, using mobile services such as SMS and MMS, or chatting via instant messenger services and playing stand-alone or networked games (Santos et al., 2007). Marketers take advantage of this trend to advertise their products within the games played, using a revolutionary service called the advergame, which is a game with advertisement capabilities (Santos et al., 2007).

In advergames the brand or product is generally a central feature of the game, whereas in in-game advertising products are more typically placed in the background of the game (e.g., as fast food restaurants in a street scene, on billboards around a sports stadium, or logos on sports equipment) (Winkler and Buckner, 2006). Advergames are interactive video games which aim to advertise and are usually hosted on the Internet, where players (usually children and young men) take the role of a character in completing certain objectives (Purswani, 2010). Besides that, they are also used to boost sales of a product or service through increased brand recognition, increased liking or other methods (Tähtinen, 2006).

Advergaming is a promising segment which is expanding rapidly with an estimated in- crease of five-fold by 2009 (Betrim, 2005). Many organizations are starting to use advergames as a part of their marketing strategy (Winker and Buckner, 2006) to improve their brand, boost product awareness and collect detailed data about existing and potential customers, clients and supporters (Afshar et al., 2004: Buckner et al., 2002).

Advergames are normally commissioned by the marketing department of an organization to promote its own brand or product and the game can frequently be accessed via the organization's corporate website (Winkler and Buckner, 2006). In-game advertising, on the other hand, is increasingly being coordinated through independent gaming organizations, such as Massive Incorporated (http://www. massiveincorporated.com/) (Winkler and Buckner, 2006).

A cross between advertising and computer games, the term 'advergaming' combines the word 'advertising' and 'video games' (Grossman, 2005), which suggests that advergames are a form of branded entertainment with the insertion of a brand within an entertainment property. Product related messages from companies are embedded in the form of game pieces, hidden treasures and other parts of the game (Neuborne. 2001: Nelson, 2002). An 'advergaming' website can be a place to play and explore and most importantly, it is generally free of charge (Obringer, 2007).

Research of brand recall and brand attitude 
on purchase intention had showed remarkable progress in contributing to the theory of buyer behavior (see Gross, 2010: Cauberghe and Pelsmacker, 2010: Lee and Faber, 2007: Nelson et al., 2004: Nelson, 2002). Although many studies have focused on brand recall and brand attitude in games-related advertising (see Jeong and Biocca, 2012: Lee and Faber, 2007: Gross, 2010: Shah et al., 2012), their impact on purchase intention in in-game advertising has not yet been well explored, especially in developing economies such as Malaysia. Previous domestic research have found that advertising position, games experience (Ing and Azizi, 2009), telepresence, product experience and interactive experience in advergaming (Hussein et al., 2010) and features of online advertising (Wei et al., 2010) are significantly related to purchase intention: and hence the attempt to emphasize brand recall, brand attitude and their mediating role will add value to the current literature on advergaming.

In addition, self-brand congruity and entertainment factors have not been investigated in the context of in-game advertising in Malaysia. Also, the influences of self-brand congruity, entertainment and brand placement as antecedents to brand recall and brand attitude are not much known and further examination is needed to discover how these factors influence consumers brand recall and brand attitude in the in-game advertising context. Therefore, self-brand congruity, entertainment and brand placement are expected to add value to the brand recall, brand attitude and purchase intention relationships.

This study aims to examine the effects of brand recall and brand attitude on purchase intention. In addition, this study also examines brand recall and brand attitude as mediators for self-brand congruity, entertainment and brand placement on purchase intention in advergames.

\section{Literature Review and Hypotheses}

\subsection{Advergames versus In-game Advertising}

As suggested by Winkler and Buckner (2006), there are differences between advergames and in-game advertising. With in-game advertising (IGA), marketers buy product placement space within an existing game. There are multiple brands present which usually remain static in the background of the main action (e.g. buying a billboard in a car-racing game) which is similar with product placements in TV shows or movies (Yang et al., 2006). In contrast, advergames are custom-online games designed specifically for a brand (Adweek Media, 2009). The brand is often central to the game-play and the game represents the brand message (Chen and Ringel, 2001). Advergames are nor- 
mally commissioned by the marketing department of an organization to promote its own brand or product and the game can be frequently accessed via the organization's corporate website (Winkler and Buckner, 2006) and placed on the brand website as part of a larger marketing strategy: they are usually free to play (Gross, 2010). In-game advertising, on the other hand, is increasingly being coordinated through independent gaming organizations, such as Massive Incorporated (http://www. massiveincorporated.com/) (Winkler and Buckner, 2006). Specifically, some IGA games require high levels of involvement (Grigorovici and Constantin, 2004) and attention to play (Lee and Faber, 2007) compared to most advergames (Winkler and Buckner, 2006).

\subsection{Self-Brand Congruity}

Self-congruity is important to hedonic consumption because the subjective experience of imagination is often led by the evaluation of the product/service image vs the consumer's self-concept (Sirgy, 1982). Self-brand congruity can be conceptualized as the match between a brand's value-expressive attributes (e.g., product/ user images) and the consumer or user's image of self (Sirgy, 1985). According to Davis et al., (2013), self-congruity is important in the context of a game due to its impact on imagination and experience. Gamers always seek a significant gap in the congruity between their own actual perceived self-concept and the ideal self (Davis et al., 2013). Gaming generates high levels of emotion and excitement (Fiore et al., 2005) which provides a platform for the experiential amplification of the internal-self (Childers et al., 2001: Scarpi, 2012).

There were remarkable findings in discussing the relationship between self-congruity and purchase intention. For example, Sirgy (1985) found that ideal congruity and self-congruity significantly influence purchase motivation. A recent study by Taylor et al., (2011) on Social Network Service advertisement showed that internal self-congruity was found as an important factor in facilitating greater attitudinal acceptance of advertisements designed to appear in the SNS context. They assumed that consumers frequently compare imagery that has been associated with a brand with images they hold about themselves. The greater the congruity, the more positive the consumer's attitude is toward the brand in question (Escalas and Bettman, 2005). A study by Sirgy et al., (2008) in extending self-image congruence research into corporate sponsorship, suggested that self-congruity with a sponsorship event has a positive influence on brand loyalty when customers are aware of the firm sponsoring the event and when it gets involved with the event. These findings showed the importance of selfcongruity in determining brand attitude.

Much research in consumer behavior has demonstrated that actual self-congruity is pos- 
itively related to consumer behavior constructs such as brand attitude, brand preference, brand choice, purchase motivation, purchase intention. brand purchase, brand satisfaction and brand loyalty (see Sohn and Kim, 2013: Sirgy et al., 2008: Sirgy, 1982, 1985: Sirgy et al., 2000: Sirgy and Su, 2000). Also, self-congruity is found to be positively related to game usage and purchase (Davis and Lang, 2013).

Thus, in this study, it is hypothesized that:

H1a: Self-brand congruity positively influences brand recall in advergames.

$H 1 b$ : Self-brand congruity positively influences brand attitude in advergames.

H1c: Self-brand congruity positively influences consumer purchase intention in advergames.

\subsection{Entertainment}

Entertainment is a component of Internet advertising. Internet advertising is more aggressive than it was previously; advertisers strive to be more creative, targeted and effective (Mangalindan et al., 2004). Now, Internet advertising includes rich media ads with animated objects that move across the consumer's screen and pop-under ads which appear onscreen after files are closed. In a game, advertising is placed in a more creative way by combining the animation elements and games to attract audience's attention to play. In pur- chase behavior, consumers not only purchase toys, but are also entertained while in the store. This will make consumers' purchasing experiences extend to complementary entertainment, which may keep them in the store longer and stimulate sales (Kim et al., 2007).

The entertainment aspect of advergames is an important source of value for gamers. It is expected to reflect the advergames' ability to enhance the experience of gamers. Uses and gratification research indicates that the entertainment value of a commercial exchange lies in its ability to fulfill the audience's needs for escapism, diversion, aesthetic enjoyment, or emotional release (Ducoffe, 1996). Ducoffe (1995: 1996) finds a significant positive relationship between entertainment and advertising value in traditional media and in Web advertising. A study of SNS users' perceptions of SNS advertisements as being entertaining and positive would influence their attitudes toward advertising appearing on the same (Taylor et al., 2011). Perceived entertainment has been identified as a determinant influencing consumers' attitudes toward advertising in electronic commerce (Gao and Koufaris, 2006: Brackett and Carr, 2001). This was supported with the recent study by Martí-Parreňo et al. (2013) who noted that entertainment is the main driver of brand attitude in advergames.

Thus, it is hypothesized that:

H2a: Entertainment positively influences brand 
recall in advergames.

$H 2 b$ : Entertainment positively influences brand attitude in advergames.

H2c: Entertainment positively influences consumer purchase intention in advergames.

\subsection{Brand Placement Acceptance}

Though the phenomenon of placing products in the entertainment media began in the early days of silent movies, progressing into the medium of television in the 1950s, the online environment only realized its potential in the 1990s (Vilafranco and Zeltzer, 2006). Brand placement refers to the practice of including a brand name product, package, signage, or other trademark merchandise within a communication medium (Hernandez et al., 2004). Balasubramanian (1994) and Schneider (2005) defined product placement as a paid product message aimed at influencing movie (and television) audiences via the planned and unobtrusive entry of a branded product into a movie (or television program). There are several limitations to this definition. It is bound to only specific media, movie or television programs and is only when payment is taking place (Schneider, 2005). Karrh (1998) also argued whether product placement could always be viewed as 'obtrusive'.

Some supported the fact that brand placement in games could destroy the fantasy world of games (Nelson, 2002: Nelson et al., 2004) and those who are negative about product placement are also negative about other types of advertisement (Hernandez et al., 2004: Nelson et al., 2004). Contrasting views were discussed by Molesworth (2005) in which most of the respondents were positive about brand placement, partly because it added realism and helped to finance the game developers. This was supported by Ho (2006) who concluded that respondents' attitude towards product placement in video games is more positive compared to placement in movies due to the fact that video games are generally not as realistic as movies, and therefore the quality of the video games is dependent on its level of realism.

A recent study by Balakrishnan et al., (2012) suggests that brand placement is positively related to brand recall on advertisement in the movies. Since the study only focused on movies, different effects may exist in games. In games specifically, brand recall was reported to amount to $30 \%$ (Nelson, 2002), and through the arousal and valence experienced by the gamer, brand attitudes were found to be positively influenced (Grigorovici and Constantin. 2004). The strength of placing a brand in an advergame does influence the advertising effects in terms of brand recall and brand attitude (Cauberghe and Pelsmacker, 2010).

Thus, it is hypothesized that:

H3a: Brand placement acceptance positively influences brand recall in advergames.

H3b: Brand placement acceptance positively 
influences brand attitude in advergames.

H3c: Brand placement acceptance positively influences consumer purchase intention in advergames.

\subsection{Brand Recall and Purchase Intention}

Many have argued the use of advergaming to be more persuasive than traditional advertising, especially on young children (Pavlou and Stewart, 2000). This was further supported by Nelson's (2002) study on familiar and non-familiar brand placement in advergames. Nelson's findings noted an almost 30 percent brand recall amongst all respondents and that 90 percent of the sample remembered at least one brand when asked immediately after the game. Hence, advergaming is a cost effective way to deliver brand message (Betrim, 2005).

Different people might experience different things and form different perceptions and attitudes. For example, in a research done on college students, as compared to their woman counterparts, men were found to be significantly more likely to play video games two or more hours a week and to indicate that video game playing interfered with sleeping and class preparation (Ogletree and Drake, 2007). In terms of brand placement and brand memory, Yang et al., (2006), in comparing college students' explicit and implicit memory for brand names, found that the said students had low levels of explicit memory (recognition test) for brands, but showed implicit memory (wordfragment test) for the brand names placed in video games. This result leads to consumer intention to purchase the product after brand exposure. The probability that a consumer plans to buy a certain brand or product during a certain period of time is set after the consumers have stored relevant information to establish the purchase decision (Howard and Sheth, 1971: Mathieson, 1991).

The impact of brand recall towards consumer attitude can be different according to the factors involved in the relationship. It was confirmed that highly congruent games lead to superior memory for the sponsoring brand in advergames (Gross, 2010). Lee and Faber (2007) in their study on on-line games found that the degree of congruity between the product category of the brand and game content influences brand memory in which highly incongruent brands are better recalled than either moderately incongruent or highly congruent brands. Besides that, when physiological arousal increased, cognitive performance (i.e. memory scores) also increased (Jeong and Biocca, 2012). Chi et al.. (2009) suggests that brand recall and brand awareness were positively related to purchase intention. This indicates that brand is an important factor that determines the consumer's purchase decision in the consumer buying behavior process.

Thus, it is hypothesized that: 
H4: Brand recall positively influences purchase intention in advergames.

H5: Brand recall positively influences brand attitude in advergames.

H7: Brand recall mediates the relationship between self-brand congruity, entertainment, brand placement acceptance and purchase intention in advergames.

\subsection{Brand Attitude and Purchase Intention}

Brand attitude is a necessary communication effect if brand purchase is to occur (Percy and Rossiter, 1992); it is undimensional, being the sum of the product of belief times evaluation. Hence, it may be fruitful to examine attitude as having multidimensional constructs consisting of networks of interconnected beliefs and evaluations (Bagozzi and Yi, 1988).

Whilst researchers found a weak correlation between attitudes towards advertising and purchase behavior (Nelson et al., 2004), favorable attitudes towards advertising had a positive effect on the individuals consumption behavior (Ing and Azizi, 2009). Researchers also claimed that attitudes towards advertising in general influenced attitudes towards advertising in games. In advergames, the change in brand attitude attributable to game enjoyment is stronger for product-relevant advergames than for product-irrelevant ones (Wise et al., 2008).

Studies have suggested that brand attitude has a positive impact on the purchasing intention of customers (Shah et al., 2012: Teng and Huihuang, 2007: Shwu-Lng and Chen-Lien, 2009). Furthermore, brand attitude strategy is seen as reflecting an interaction between a potential consumer's involvement with the purchase decision and the underlying motivation to purchase (Percy and Rossiter, 1992). This supports our prediction that brand attitude may affect consumer behavior during game playing. As a mediating role, attitude toward the ad is receiving increasing attention as a mediator of advertising effects (Lutz et al., 1983). Recent study on the impact of event marketing on brand equity by Zarantonello and Schmitt (2012) found that brand attitudes mediate the relationship between events and brand equity only for certain types of events. Since those studies have not given emphasis to advergames, the current study attempts to fill this gap.

Thus, it is hypothesized that:

H5: Brand attitude positively influences purchase intention in advergames.

H8: Brand attitude mediates the relationship between self-brand congruity, entertainment, brand placement acceptance and purchase intention in advergames. 


\section{Method and Results}

\subsection{Method}

The sample for this study was collected through an online survey of gamers in Malaysia. The respondents were contacted and asked whether they were playing video, mobile, or SNS games. After that, they were guided to click on a link to an online questionnaire. If they did not play games, they were asked to introduce their game-playing friends to participate in this study. A total of three hundred and fifty respondents were contacted via email and Facebook to participate in this study. They were contacted through email based on suggestions from friends of the author. Besides personal email invitations, participants were also invited through links placed in social networks such as Facebook.

For this study, a structured online survey questionnaire was designed. There are several reasons of using an online survey. Firstly, it saves on printing costs. Secondly, the online survey was specifically designed to encourage respondents to answer all the questions covered. For example, if the respondent had not finished answering the first question, they would not be able to move on to the next question. Thirdly, online surveys can reach a wide number of respondents. Fourthly, it saves the respondent's time in answering the questions.
For example, a test was conducted to compare the time consumed between online and offline surveys. The results showed that online surveys save almost half the respondent's time in completing the questionnaires compared to offline surveys.

Respondents were asked whether they have experienced in-game advertisement during game playing. To test the respondent's memory on the brand which appeared in the game, they were asked to recall the said brands without being asked to play the game. This is to encourage the respondents to recall the brands which they saw or noticed in the game in a natural viewing environment. This approach is different with most advertising effectiveness studies which used experimental control and artificial stimuli to test respondent's memory.

The measurements used in this study were adopted from previous studies and modified to suit the context of this study and survey approach. Self-brand congruity measurement was adapted from Sirgy et al., (1997) which measured the match between a brand's value expression attributes and the consumer's selfimage (Sirgy, 1985) among gamers. An entertainment measurement was adapted from Ducoffe (1996) which measures whether the advergames are attractive, entertaining, enjoyable, fun, pleasing and exciting to gamers. For brand placement acceptance, it measures the consumers' acceptance of the brand and product existence in games and their perceptions of brands which 
appeared in the games they played in (Morton and Friedman, 2002). Brand recall also was adapted from Morton and Friedman (2002) which measures the extent of gamers recall of brands placed in games and also their preferences compared with that of the commercial format. Brand attitude was adapted from Batra and Stayman (1990) which measures consumers' attitude towards the brands which they saw in the games: in other words, whether the brands appeared were bad/good, not lovable/ lovable, not desired/ desired and negative/ positive. Finally, purchase intention was adapted from Morton and Friedman (2002) which measures a consumer's level of intention to purchase the brands, which appeared in games, in the future. All measurements were measured by 5 -point Likert scales of "1 = strongly disagree" to " $5=$ strongly agree". The Cronbach's alpha estimated for self-brand congruity was 0.856 , entertainment was 0.946 , brand placement was 0.839 , brand recall was 0.862 , brand attitude was 0.874 and purchase intention was 0.828 . As the Cronbach's alphas in this study were all much higher than 0.6. the constructs were therefore deemed to have adequate reliability.

A total of 350 respondents participated in this study and managed to complete an online survey. Table 1 shows their sample profile by gender, age, time spent in a week playing games, preferred game mode, preferred game and type of game played referred to when this survey was conducted.

〈Table 1〉 Respondent profile

\begin{tabular}{llr}
\hline & Profile & $\mathrm{N}=350$ \\
\hline Gender & Male & 167 \\
& Female & 183 \\
Age & 19-20 years & 47 \\
& 21-25 years & 156 \\
& 26-30 years & 95 \\
Time spend & $>$ 30 years & 52 \\
(hours in a week) & 1-8 Hours & 16 \\
& $>8$ hours & 259 \\
Game mode & Single player & 250 \\
\multirow{4}{*}{ Preferred game } & Multiple player & 100 \\
& Free game & 333 \\
Type of game & Paid game & 17 \\
& Video game & 114 \\
& Mobile game & 126 \\
& SNS game & 110 \\
\hline
\end{tabular}

\subsection{Results}

Table 2 presents the results of a multiple regression analysis used to evaluate the strength of the proposed relationship. In model 1 , it was revealed that $\mathrm{H} 2 \mathrm{a}$ and $\mathrm{H} 3 \mathrm{a}$ were found to be significant in the prediction model, which provides support for hypotheses $\mathrm{H} 2 \mathrm{a}$ and $\mathrm{H} 3 \mathrm{a}$ referring to the relationship between entertainment $(\beta=0.145: \mathrm{p}<0.05)$ and brand placement on brand recall $(\beta=0.520: \mathrm{p}<0.001)$. However, self-brand congruity was found to have no significant relationship with brand recall $(\beta=0.052: p>0.05)$, or Hla is rejected. In model $2, \mathrm{H} 1 \mathrm{~b}, \mathrm{H} 2 \mathrm{~b}$ and $\mathrm{H} 3 \mathrm{~b}$ were found to 
〈Table 2〉 The relationship between self-brand congruity, entertainment, brand placement, brand recall, brand attitude and purchase intention

\begin{tabular}{|l|c|c|c|c|c|c|c|c|}
\hline \multicolumn{1}{|c|}{$\begin{array}{c}\text { Dependent } \\
\text { variables }\end{array}$} & \multicolumn{2}{|c|}{ Multi-collinearity } & \multicolumn{2}{c|}{$\begin{array}{c}\text { Model 1 } \\
\text { (Brand recall) }\end{array}$} & \multicolumn{2}{c|}{$\begin{array}{c}\text { Model 2 } \\
\text { (Brand attitude) }\end{array}$} & \multicolumn{2}{c|}{$\begin{array}{c}\text { Model 3 } \\
\text { (Purchase intention) }\end{array}$} \\
\hline & Tol & VIF & $\mathrm{t}$ & $\beta$ & $\mathrm{t}$ & $\beta$ & $\mathrm{t}$ & $\beta$ \\
\cline { 2 - 9 } & & & 3.455 & & 3.101 & & 4.858 & \\
(Constant) & & & 1.179 & 0.052 & 1.838 & $0.088^{*}$ & 3.016 & $0.144^{* *}$ \\
Self-brand \\
congruity & 0.875 & 1.143 & & & & & & \\
Entertainment & 0.585 & 1.711 & 2.753 & $0.145^{* *}$ & 4.701 & $0.271^{* * *}$ & 2.722 & $0.156^{* *}$ \\
Brand placement & & & & & & & & \\
acceptance & 0.574 & 1.742 & 9.755 & $0.520^{* * *}$ & 5.007 & $0.292^{* * *}$ & 6.427 & $0.373^{* * *}$ \\
R Square & & & 0.409 & & 0.294 & & 0.302 & \\
Adjusted R Square & & & 0.404 & & 0.287 & & 0.296 & \\
F-Statistics & & & 79.742 & & 47.926 & & 49.901 & \\
Sig. & & & 0.00 & & 0.000 & & 0.000 & \\
\hline
\end{tabular}

${ }^{*}$ Significance at $0.10,{ }^{* *}$ Significance at $0.05,{ }^{* * *}$ Significance at 0.001

be significant in the prediction model, which provides support for hypotheses $\mathrm{H} 1 \mathrm{~b}, \mathrm{H} 2 \mathrm{~b}$ and $\mathrm{H} 3 \mathrm{~b}$, referring to the relationship between self-brand congruity $(\beta=0.088: p<0.10)$, entertainment $(\beta=0.271: \mathrm{p}<0.001)$, and brand placement and brand attitude $(\beta=0.292: \mathrm{p}<$ 0.001). In model 3 in which purchase intention was considered as a dependent variable, all dependent variables were found to be significant in the prediction model, which provides support for hypotheses H1c, H2c, and $\mathrm{H} 3 \mathrm{c}$ referring to the relationship between self-brand congruity ( $\beta=1.44 ; \mathrm{p}<0.05)$, entertainment $(\beta=$ $0.156: \mathrm{p}<0.05)$, and brand placement acceptance and brand attitude $(\beta=0.373: p<0.001)$.

Table 3 presents the results of a multiple regression analysis used to examine the relationship between brand recall, brand attitude and purchase intention. The model revealed that brand recall and brand attitude were found to be significant in the prediction model, that is, there is a relationship between brand recall ( $\beta=0.413 ; \mathrm{p}<0.001)$, and brand attitude on purchase intention $(\beta=0.360 ; \mathrm{p}<0.001)$. Thus, H4 and H5 are supported. Hypotheses 6 suggests a relationship between brand recall and brand attitude. The results show that brand recall is positively related with brand attitude, in other words, the relationship between brand recall on brand attitude $(\beta=0.484 ; \mathrm{p}<0.001)$ in advergames is significant (Table 4). Thus, H6 is supported.

Table 5 presents the hierarchical regression to examine the mediating effects of brand recall and brand attitude in the relationships between self-brand congruity, entertainment and 
〈Table 3$\rangle$ The relationship between brand recall, brand attitude and purchase intention

\begin{tabular}{|l|r|r|}
\hline Model 4 (Dependent variable: Purchase Intention) & $\mathrm{t}$ & $\beta$ \\
\hline (Constant) & 6.360 & $0.413^{* * *}$ \\
Brand recall & 9.032 & $0.360^{* * *}$ \\
Brand attitude & 7.864 & \\
R Square & 0.444 & \\
Adjusted R Square & 0.441 & \\
F-Statistics & 138.660 & \\
Sig. & 0.000 & \\
\hline
\end{tabular}

*** Significance at 0.001

$\langle$ Table 4$\rangle$ The relationship between brand recall and brand attitude

\begin{tabular}{|l|r|r|}
\hline Model 4 (Dependent variable: Brand attitude) & $\mathrm{t}$ & $\beta$ \\
\hline (Constant) & 8.412 & $0.484^{* * *}$ \\
Brand recall & 10.330 & \\
R Square & 0.235 & \\
Adjusted R Square & 0.232 & \\
F-Statistics & 106.716 & \\
Sig. & 0.000 & \\
\hline
\end{tabular}

${ }^{* * *}$ Significance at 0.001

brand placement on purchase intention. In model 1 , the $\mathrm{R}$ square value indicated that $30.2 \%$ of the variance in purchase intention can be explained by self-brand congruity, entertainment and brand placement acceptance $(\mathrm{F}=49.901$; $\mathrm{p}<0.001)$. The results also showed that selfbrand congruity $(t=3.016: p<0.05)$, entertainment $(t=2.722 ; \mathrm{p}<0.05)$ and brand placement $(t=6.427: p<0.001)$ are significantly related with purchase intention. With the inclusion of brand recall and brand attitude in model 2 , the $\mathrm{R}$ square value indicated that $46.5 \%$ of the variance in purchase intention can be explained by self-brand congruity, entertainment, brand placement, brand recall and brand attitude $(\mathrm{F}=59.803: \mathrm{p}<0.001)$.

To test for mediation, we applied Baron and Kenney's method which used the computation of three regression models. The first regression is between the independent variable and the intervening variable. The second regression is between independent variable and dependent variable and finally, the dependent variable is regressed on both the independent and intervening variables as shown in the research hypotheses. 
〈Table 5〉 Hierarchical regression: the relationships between self-brand congruity, entertainment, brand placement, brand recall and brand attitude on purchase intention

\begin{tabular}{|l|l|c|c|c|c|}
\hline & Model (Dependent variable: & \multicolumn{2}{|c|}{ Brand recall is controlled } & \multicolumn{2}{c|}{ Brand attitude is controlled } \\
\cline { 3 - 6 } & & $\mathrm{t}$ & $\beta$ & $\mathrm{t}$ & $\beta$ \\
\hline Model 1 & (Constant) & 4.858 & & 4.858 & \\
& Self-brand congruity & 3.016 & $0.144^{* *}$ & 3.016 & $0.144^{* *}$ \\
& Entertainment & 2.722 & $0.156^{* *}$ & 2.722 & $0.156^{* *}$ \\
& Brand placement acceptance & 6.427 & $0.373^{* * *}$ & 6.427 & $0.373^{* * *}$ \\
& R Square & 0.302 & & 0.302 & \\
& Adjusted R Square & 0.296 & & 0.296 & \\
& R Square change & 0.302 & & 0.302 & \\
& F-Statistics & 49.901 & & 49.901 & \\
& Sig. & $0.000^{* * *}$ & & $0.000^{* * *}$ & \\
\hline Model 2 & (Constant) & 3.155 & & 3.155 & \\
& Self-brand congruity & 2.767 & $0.123^{* *}$ & 2.489 & $0.110^{* * *}$ \\
& Entertainment & 1.796 & $0.096^{*}$ & 0.975 & 0.053 \\
& Brand placement acceptance & 2.623 & $0.159^{* *}$ & 4.713 & $0.262^{* * *}$ \\
& Brand recall Brand attitude & 7.564 & $0.410^{* * *}$ & 7.653 & $0.379^{* * *}$ \\
& R Square & 0.401 & & 0.403 & \\
& Adjusted R Square & 0.394 & & 0.396 & \\
& R Square change & 0.099 & & 0.101 & \\
& F-Statistics & 57.812 & & 58.293 & \\
& Sig. & $0.000^{* * *}$ & & $0.000^{* * *}$ & \\
\hline
\end{tabular}

${ }^{*}$ Significance at $0.10,{ }^{* *}$ Significance at $0.05,{ }^{* * *}$ Significance at 0.001

According to Baron and Kenny (1986), these three regression equations provide the tests of linkages of the mediational model. To establish mediation, the following conditions must hold: first, the independent variable must affect the mediator in the first equation: second, the independent variable must be shown to affect the dependent variable in the second equation: and third, the mediator must affect the dependent variable in the third equation. If these conditions all hold in the predicted direction, then the effect of the independent variable on the dependent variable must be less in the third equation than in the second. Perfect mediation holds if the independent variable has no effect when the mediator is controlled. The hierarchical regression results also showed that brand recall (Table $4, \beta=0.410: \mathrm{p}<0.001$ ) and brand attitude (Table 5, $\beta=0.379$ : $\mathrm{p}<$ 0.001 ) mediate the relationship between self- 
brand congruity, entertainment, brand placement and purchase intention. Thus, $\mathrm{H} 7$ and $\mathrm{H} 8$ are supported.

As summarized in Table 6, the results of the four regression models for mediation (brand recall and brand attitude) show that the effect of self-brand congruity, entertainment and brand placement on purchase intention is much less in the fourth model compared to the third. Nevertheless, the R square has improved from 0.302 (Model 3) to 0.401 (Model 4) for brand recall and to 0.403 (Model 5) for brand attitude. This value improvement indicated that the fourth model allows partial mediation to $\mathrm{ex}^{-}$ plain more variance than the third model without considering the mediating variables of brand recall and brand attitude. The lower $\mathrm{R}$ square values shown in Models 4 and 5 compared with Model 3 indicated that the variance of the population is more favorably explained by the data. A perfect mediation cannot be claimed since the independent variables in Model 4 and Model 5 are still significant. However, the decrease of the $\beta$ value from Model 3 to Model 4 and Model 5 show the mediating effects.

\section{General Discussion}

\subsection{Summary of Findings}

This study aims to examine the impact of brand recall and brand attitude on purchase intention in advergames among Malaysian gamers. The antecedents towards brand recall and brand attitude were also examined to measure their influences on purchase intention. The re-

〈Table 6〉 The regression models testing the mediating variables of brand recall and brand attitude

\begin{tabular}{|l|c|c|c|c|c|}
\hline \multicolumn{1}{|c|}{ Y } & $\begin{array}{c}\text { Model 1 } \\
\text { Brand recall }\end{array}$ & $\begin{array}{c}\text { Model 2 } \\
\text { Brand } \\
\text { attitude }\end{array}$ & $\begin{array}{c}\text { Model 3 } \\
\text { Purchase } \\
\text { intention }\end{array}$ & $\begin{array}{c}\text { Model 4 } \\
\text { Purchase intention } \\
\text { (Brand recall is } \\
\text { controlled) }\end{array}$ & $\begin{array}{c}\text { Model 5 } \\
\text { Purchase intention } \\
\text { (Brand attitude is } \\
\text { controlled) }\end{array}$ \\
\hline $\begin{array}{l}\text { Self-brand congruity } \\
\text { Entertainment }\end{array}$ & 0.052 & $0.088^{*}$ & $0.144^{* *}$ & $0.123^{* *}$ & $0.110^{* *}$ \\
Brand placement & $0.145^{* *}$ & $0.271^{* * *}$ & $0.156^{* *}$ & $0.096^{*}$ & 0.053 \\
acceptance & $0.520^{* * *}$ & $0.292^{* * *}$ & $0.373^{* * *}$ & $0.159^{* *}$ & $0.262^{* * *}$ \\
Brand recall & & & & $0.410^{* * *}$ & \\
Brand attitude & 0.409 & 0.294 & 0.302 & 0.401 & $0.379^{* * *}$ \\
R Square & 79.742 & 47.926 & 49.901 & 57.812 & 0.403 \\
R Square change & & & 0.302 & 0.101 \\
F-Statistics & & & & \\
\hline
\end{tabular}

*Significance at $0.10,{ }^{* *}$ Significance at $0.05,{ }^{* * *}$ Significance at 0.001 
sults showed that except for direct effects between self-brand congruity, brand recall and brand attitude, all hypotheses were supported for Malaysian consumers.

It was found that self-brand congruity has a significant influence on brand attitude and purchase intention. When users see the brand which matches with them, they tend to act positively toward the brand exposed in the game. This is consistent with Escalas and Bettman (2005) who suggested that the greater the congruity, the more positive the consumer's attitude toward the brand in question. This leads to game usage and purchase (Davis and Lang, 2013).

In the advergaming context, the entertainment value in advergames is very important to determine the level of enjoyment and pleasure experienced by gamers during game-playing. Therefore, the more entertaining the ads, the more it will be remembered and the greater the positive behavior of the consumer towards the advergames - this ultimately stimulates their intention to purchase the brand.

This study shows the effect of brand placement on brand recall and brand attitude and also purchase intention. Brand placements might not work in games due to the interactivity involved in game-playing as people could be distracted from noticing the brand placements (Yang et al., 2006). However, the significant influence of brand placements found in this study may provide major promise for advertisers.
Game players may or may not explicitly remember the brands they see in the games, but these placements may influence their brand recall and brand attitude and could therefore influence later decisions (Yang et al., 2006).

In this study, it was found that self-brand congruity was not significantly related with brand recall. The reason for this could be attributed to the fact that this study examined gamers who are highly involved in the interactive medium of games which force them to focus on game play rather than advertisements: the level of recognition to remember the brand exposed in the game is low and contributes to the "mismatch" between the gamers and the said brand. The overall result of this study has been summarized in Table 7 . communication literature. Their mediating role may provide new insights on how they facilitate the effects of self-brand congruity, entertainment and brand placement on purchase intention. Besides that, the studies on the influence of self-brand congruity on brand recall and brand attitude and also consumer intention to purchase had not been well-investigated in advergames. This study contributes to fill those gaps in advergames literature.

For practitioners, this study could suggest the use of illustrative or demonstrative placements of new products to help customers remember new brands, and the use of associative placements for existing products to increase consumers' purchase intention (Ho et al., 2011). 
〈Table 7〉 The summary of the overall results of the relationship between self-brand congruity, entertainment, brand placement acceptance, brand recall, brand attitude and purchase intention.

\begin{tabular}{|l|l|l|l|}
\hline H1 & a & Self-brand congruity positively influences brand recall in advergames & Rejected \\
\hline & b & Self-brand congruity positively influences brand attitude in advergames & Supported \\
\hline & c & Self-brand congruity positively influences purchase intention in advergames & Supported \\
\hline H2 & a & Entertainment positively influences brand recall in advergames & Supported \\
\hline & b & Entertainment positively influences brand attitude in advergames & Supported \\
\hline & c & Entertainment positively influences purchase intention in advergames & Supported \\
\hline H3 & a & Brand placement acceptance positively influences brand recall in advergames & Supported \\
\hline & b & Brand placement acceptance positively influences brand attitude in advergames & Supported \\
\hline & c & Brand placement acceptance positively influences purchase intention in advergames & Supported \\
\hline H4 & & Brand recall positively influences purchase intention in advergames & Supported \\
\hline H5 & & Brand attitude positively influences purchase intention in advergames & Supported \\
\hline H6 & & Brand recall positively influences brand attitude in advergames & Supported \\
\hline H7 & & $\begin{array}{l}\text { Brand recall mediates the relationship between self-brand congruity, entertainment, } \\
\text { brand placement acceptance and advergames }\end{array}$ & Supported \\
\hline H8 & & $\begin{array}{l}\text { Brand attitude mediates the relationship between self-brand congruity, } \\
\text { entertainment, brand placement acceptance and advergames }\end{array}$ & Supported \\
\hline
\end{tabular}

To advertisers, this study may provide useful information to improve their current advertising strategies in games, for instance, by considering game players' congruity, entertainment value and brand placement factors.

Since the present study employed online survey instead of experimental study to test brand recall effectiveness, this would give new direction for future research to test audience memory on advertising effectiveness in a natural viewing environment. This is because experimental studies usually tend to suffer from unnatural viewing environments, short-duration experimental stimuli and artificial stimuli (Shrum et al., 2009). Through appropriate procedures, survey $\mathrm{re}^{-}$ search would give meaningful understanding to media communication research.

\subsection{Limitations and Directions for Future Research}

This present study examines the impact of antecedents of brand recall and brand attitude towards purchase intention and also the role of brand recall and brand attitude as mediators in advergames. However, this study is subject to several limitations. Firstly, the respondents were drawn from the researcher's list of friends' social networks. This is due to the time constraints faced by the researcher in conducting this study. Secondly, the type of game genre was not specified in the testing of the effects of 
brand recall and brand attitude, and their antecedents on purchase intention, eventhough the scope covered three types of popular games played namely video, mobile and SNS games. A study on the specific game genre will give better understanding for future research. Finally, the present study suggests the impact of selfbrand congruity in influencing brand recall and brand attitude in advergames. Therefore, future research to examine its effects on other dominant factors would give more understanding in determining the success of in-game advertising strategies.

〈Received July 13. 2013〉

〈1st Revised August 31. 2013〉

〈2nd Revised September 18. 2013〉

〈Accepted September 23. 2013〉

\section{References}

AdWeek Media (2009), "Game on! The ActionPacked World of Videogame Advertising. Custom Report for Adweek, Brandweek, and Mediaweek," 〈http://www.adweek. com/aw/photos/stylus/43082-1020Video Games-lo-res.pdf $\rangle$. (accessed on 10/12/2009) Afshar, R., Jones, C., and Banerjee, D. (2004). Advergaming Developer's Guide. Hingham, Massachusetts: Charles River Media.

Bagozzi, R.P., and Yi, Y. (1988), "On the evaluation of structural equation models," Journal of the Academy Marketing Science, Vol. 16, No. 1, pp. 74-94.

Balakrishnan, B. KPD., Shuaib, A.S.M, Dousin, O. and Permarupan, P.Y. (2012), "The Impact of Brand Placement and Brand Recall in Movies: Empirical Evidence from Malaysia," International Journal of Management and Marketing Research, Vol. 5, No. 2. pp. 39-52.

Balasubramanian, S. K. (1994), "Beyond Advertising and Publicity: Hybrid Messages and Public Policy Issues," Journal of $\mathrm{Ad}^{-}$ vertising, Vol. 23, No. 4, pp. $29-46$.

Baron, R.M. and Kenny, D.A. (1986), "The Moderator-Mediator Variable Distinction in Social Psychological Research: Conceptual . Strategic, and Statistical Considerations," Journal of Personal and Social Psychology, Vol. 51, No. 6, pp. 1173-1182.

Batra, R. and Stayman, D.M. (1990), “The Role of Mood in Advertising Effectiveness," Journal of Consumer Research, Vol, 17, pp. 203-214.

Bertrim, B. (2005), "It's How You Play the Games," Marketing Magazine, Vol. 110, No. 16, p.18.

Brackett, L. and Carr, B.N. (2001), "Cyberspace Advertising vs. Other Media: Consumer vs. Mature Student Attitudes," Journal of Advertising Research, Vol. 41, No. 5, pp. 23-32.

Buckner, K., Fang, H. and Qiao, S. (2002). "Advergaming: A New Genre in Internet 
Advertising," 〈http://www.dcs.napier.ac. $\left.u k / \sim m m / s o c b y t e s / f e b 2002 \_i / 9 . h t m l\right\rangle$ (accessed on 9/05/2006).

Cauberghe, V. and Pelsmacker, P.D. (2010), "The Impact of Brand Prominence and Game Repetition on Brand Response," Journal of Advertising, Vol. 39, no. 1, pp. 5-18.

Chen, J., and Ringel, M. (2001), "Can Advergaming $\mathrm{Be}$ the Future of Interactive $\mathrm{Ad}^{-}$ vertising?" 〈http://www.kpe.com〉. (accessed on $18 / 12 / 2012$ )

Childers, T.L., Carr, C.L., Peck, J. and Carson, S. (2001), "Hedonic and Utilitarian Motivations for Online Shopping Behavior," Journal of Retailing, Vol. 77, No. 4, pp. 246-61.

Chi, H.K., Yeh, H.R. and Yang, Y.T. (2009), "The Impact of Brand Awareness on Consumer Purchase Intention: The Mediating Effect of Perceived Quality and Brand Quality," The Journal of International Management Studies, Vol. 4. No. 1, pp. 135144.

Davis, R. and Lang, B. (2013), "Does Game Self-Congruity Increase Usage and Purchase?" Young Consumers, Vol. 14, No. 1. pp. 52-66.

Davis, R., Lang, B. and Gautam, N. (2013), "Modeling Utilitarian-Hedonic Dual Mediation (UHDM) in the Purchase and Use of Games," Internet Research, Vol. 23, No. 2, pp. 229-256.

Davis, R. and Lang, B. (2012), "Modelling the
Effect of Self-Efficacy on Game Usage and Purchase Behavior," Journal of Retailing and Consumer Services, Vol. 19, pp. 67-77.

Davis, R. and Lang, B. (2012), "Modelling Game Usage, Purchase Behavior and Ease of Use," Entertainment Computing. Vol, 3, pp. 27-36.

Ducoffe, R.H. (1995), "How Consumers Assess the Value of Advertising," Journal of Current Issues and Research in Advertising, Vol. 17, No. 1, pp. 1-18.

Ducoffe, R.H. (1996), "Advertising Value and Advertising on the Web," Journal of Advertising Research, Vol. 36, No. 5, pp. 2134.

Escalas, J.E. and Bettman, J.R. (2005), "SelfConstrual, Reference Groups, and Brand Meaning," Journal of Consumer Research. Vol. 32, pp. 378-389.

Farrar, K. M., Krcmar, M. and Nowak, K.L. (2006), “Contextual Features of Violent Video Games, Mental Models and Aggression," Journal of Communication, Vol. 56. No. 2, pp. 387-405.

Fiore, A., Jin, H. and Kim, J. (2005), "For Fun and Profit: Hedonic Value from Image Interactivity and Responses Toward an Online Store," Psychology and Marketing. Vol. 22, No. 8, pp. 669-94.

Gao, Y. and Koufaris, M. (2006), "Perceptual Antecedents of User Attitude in Electronic Commerce," The DATA BASE for Ad- 
vances in Information Systems, Vol. 37, No. $2 \& 3$, pp. $42-50$.

Grigorovici, D.M. and Constantin, C.D. (2004), "Experiencing Interactive Advertising beyond Rich Media: Impact of Ad Type and Presence on Brand Effectiveness in 3D Gaming Immersive Virtual Environment," Journal of Interactive Media, Vol. 5, No. 1, pp. 31-53.

Gross, M.L. (2010), "Advergames and The Effects of Game-Product Congruity," Computers in Human Behavior, Vol. 26, pp. 1259-1265.

Grossman, S. (2005), "Grand Theft Oreo: The Constitutionality of Advergame Regulation," Yale Law Journal, Vol. 115, October, pp. 227-237.

Ho, R., (April 2006), "Videogames that sell," Creativity, Vol. 14, No. 4, pp. 21.

Ho, S.-H., Lin, Y.-L., and Yang, Y.-T. (2011), "In-Game Advertising: Consumers" Attitude and The Effect of Product Placements on Memory," African Journal of Business Management, Vol. 5, No. 24, pp. 10117-10127. Ho, C.-H. and Wu, T.-Y. (2012), "Factors Affecting Intent to Purchase Virtual Goods in Online Games," International Journal of Electronic Business Management, Vol. 10, No. 3, pp. 204-212.

Hernandez, M.D., Chapa, S., Minor, M.S., Maldonado, C., and Barranzuela, F. (2004), "Hispanic attitudes toward advergames: a proposed model of their antecedents," Journal of Interactive Advertising, Vol, 5, No. 1, pp. 74-83.

Hussein, Z., Wahid, N.A. and Saad, N. (2010), "Evaluating Telepresence Experience and Game Players' Intention to Purchase Product Advertised in Advergame," World Academy of Science, Engineering and Technology, Vol. 42, pp. 1611-1616.

Howard, J.A. and Sheth, J.N. (1971), "A Theory of Buyer Behavior", Journal of Marketing , Vol. 35, No. 1, pp. 467-487.

Ing, P. and Azizi A.A. (2009), "The Impact of Advertising Position and Games Experience on Purchase Intention in Advergaming," Interdisciplinary Journal of Contemporary Research in Business, Vol. 1, No. 4, pp. 40-51.

Jeong, E.J. and Biocca, F.A. (2012), "Are There Optimal Levels of Arousal to Memory? Effects of Arousal, Centrality, and Familiarity on Brand Memory in Video Games," Computers in Human Behavior, Vol, 28, pp. 285-291.

Karrh, J. A. (Fall 1998), "Brand Placement: A Review." Journal of Current Issues and Research in Advertising, Vol. 20, No. 2, pp 31-49.

Kim, Y.-K., Sullivan, P. and Forney, J.C. (2007), Experiential Retailing: Concepts and Strategies that Sell, Fairchild Publications, Inc. New York.

Lee, M. and Faber, R.J. (2007), "Effects of Product Placement in On-Line Games on 
Brand Memory," Journal of Advertising. Vol. 36, No. 4, pp. 75-90.

Lui, F., Li, J., Mizerski, D. and Soh, H. (2012), "Self-Congruity, Brand Attitude, and Brand Loyalty: A Study on Luxury Brands," European Journal of Marketing, Vol. 46, No. 7/8, pp. 922-937.

Lutz, R.J., MacKenzie, S.B. and Belch, G.E. (1983), "Attitude Toward the Ad as a Mediator of Advertising Effectiveness: Determinants and Consequences," In R.P. Bagozzi and A.M. Tybout, A. Abor (eds), Advances in consumer research, Vol. 10, pp. 532-539, UT: Association for Consumer Research.

Mangalindan, M., Swisher, K., Bank, D., Hamilton, D.P. and Clark, D. (2004), "Starting to Click: After Wave of Disappointments, the Web Lures Back Advertisers: New Generation of Pitches Nets Data on Consumers: Not a Mass Audience; Getting Drivers to Showroom," The Wall Street Journal, Eastern edition, February 9, R.3.

Martí-Parreňo, J., Aldás-Manzano, J., CurrásPérez, R. and Sánchez-García, I. (2013), "Factors Contributing Brand Attitude in Advergames: Entertainment and Irritation," Journal of Brand Management, Vol. 20, pp. 374-388.

Mathieson, K. (1991), "Predicting user intentions: comparing the technology acceptance model with the theory of planned behavior," Information Systems Research, Vol, 2, No.
3, pp. 173.

Molesworth, M. (2005), Real brands in imaginary worlds: Investigating players' experiences of brand placement in digital games, Version 348 revised Jan 2005, Bournemouth University, Media School.

Morton, C.R., and Friedman, M. (2002), "I saw it in the movie: exploring the link between product placement beliefs and reported usage behavior," Journal of Current Issues and Research in Advertising, Vol. 24, No. 2. pp. 33-40.

Nelson, M. R. (2002), "Recall of Brand Placements in Computer/Video Games," Journal of Advertising Research, Vol. 42, No. 2, pp. 80-92.

Nelson, M. R., Keum, H., \& Yaros, R. A. (2004), "Advertainment or Adcreep? Game Players' Attitudes toward Advertising and Product Placements in Computer Games," Journal of Interactive Advertising, Vol, 5, No. 1, pp 3-30.

Neuborne, E. (2001), "For Kids on the Web, It's an Ad, Ad, Ad, Ad World," Business Week. Vol. 3475, August 13, pp.108-109.

Obringer, L.A. (March 13, 2007), "How Advergaming Works," Howstuffworks.com. online. http://www.Howstuffworks.com/ advergaming.html. (accessed on 18/04/2013 ) Ogletree and Drake. (2007), "College Students' Video Game Participation and Perception: Gender Differences and Implications," Sex Roles, Vol. 56, pp.537-542. 
Pavlov, P.A. and Stewart, D.W. (2000), "Measuring the Effects and Effectiveness of Interactive Advertising: A Research Agenda," Journal of Interactive Advertising, Vol. 1, No. 1. Available at www.jiad.org

Percy, L. and Rossiter, J.R. (1992), “A Model of Brand Awareness and Brand Attitude Advertising Strategies," Psychology \& Marketing, Vol. 9, No. 4, pp. 263-274.

Purswani, G. (2010), “Advergames, their use and potential regulation," Asia Pacific Public Relations Journal, Vol. 11, pp. 57-63.

Santos, E., Gonzalo, R. and Gisbert, F. (2007), "Advergames: Overview," Intemational Journal Information Technologies and Knowledge, Vol. 1, pp. 203-208.

Scarpi, D. (2012), "Work and Fun on the Internet: The Effects of Utilitarianism and Hedonism Online," Journal of Interactive Marketing. Vol. 26. No. 1. pp. 53-67.

Schneider, L. and Cornwall, B. (2005), “Cashing In on Crashes via Brand Placement in Computer Games: The Effects of Experience and Flow," International Journal of Advertising, Vol, 24, No. 3, pp 321-343.

Shah, S.S.H., Aziz, J., Jaffari, A.R., Waris, S., Ejaz, W., Fatima, M. and Sherazi, S.K. (2012), "The Impact of Brands on Consumer Purchase Intentions," Asian Journal of Business Management, Vol. 4, No. 2, pp. 105-110.

Shon, Y.S. and Kim, S.E. (2013), "Inverse Effects of Information: The Influence of
Personality Congruence on Preference for High Technology Products," Asia Marketing Journal, Vol. 14, No. 4, pp. 167-188.

Shrum, L.J., Lowrey, T.M., and Liu, Y. (2009), "Emerging issues in advertising research. In Nabi, R.L. and Oliver, M.B. (Ed.)," The SAGE Handbook of Media Processes and Effects (pp. 299-312). SAGE Publications, Inc.

Shwu-Lng, W., and Chen-Lien, L. (2009), “The influence of core brand attitude and core brand perception on purchase intention towards extended product," Journal of Marketing Logistics, Vol. 21, No. 1, pp. 174-194.

Sirgy, M.J. (1982), “Self-Concept in Consumer Behavior: A Critical Review," Journal of Consumer Research, Vol. 9, No. 3, pp. 287-300.

Sirgy, M.J. (1985), "Self-image/product-image congruity and consumer decision-making," International Journal of Management, Vol. 2. pp. 49-63.

Sirgy, M.J., Lee, D.-J., Johar, J.S. and Tidwell, J. (2008), "Effect of Self-Congruity with Sponsorship on Brand Loyalty," Journal of Business Research, Vol. 61, pp. 1091-1097. Sirgy, M.J., Grewal, D, Mangleburg, T. (2000), "Retail environment, self-congruity, and retail patronage: an integrative model and research agenda," Journal of Business Research, Vol. 49, pp. 127-138.

Sirgy, M.J. and Su, C. (2000), "Destination 
image, self-congruity, and travel behavior: toward an integrative model," Journal of Travel Research, Vol. 38, pp. 340-352.

Tähtinen, J. (2006), "Mobile advertising or mobile marketing. A need for a new concept?" Conference Proceedings of Frontiers of e-Business Research 2005, pp. 152-164.

Taylor, D.G, Lewin, J.E, and Strutton, D. (2011), "Friends, Fans, and Followers: Do Ads Work on Social Networks? How Gender and Age Shape Receptivity," Journal of Advertising Research, Vol. 51, No. 1, pp. 258-275.

Teng, L.L.M. and Huihuang, Z. (2007), "The effects of multiple-ads and multiple-brandson consumer attitude and purchase behavior," Journal of Consumer Marketing, Vol. 24, No. 1, pp. 27-35.

Van der Graff. S. and Nieborg, D.B. (2003), "Together We Brand: America's Army. In Level Up: Digital Games Research Conference. M. Copier and J. Raessens," eds., Utrecht University 〈http:www.digra.org〉 $d / / d b / 05163.34543\rangle$ (accessed on 10/05/2007).

Villafranco, J. E. and A. N. Zeltzer (2006), "Product Placement and Brand Integration Strategies: Managing the Risks of Regulatory Uncertainty," Consumer Protection Update, Vol. 13, No. 1. http://www. colliershannon.com/documents/CPU_JEV 2.pdf (accessed on 10/05/2007).
Wei, K.K., Jerome, T. and Shan, L.W. (2010), "Online Advertising: A Study of Malaysian Consumers," International Journal of $\mathrm{Bu}$ siness and Information, Vol. 5, No. 2, pp. 111-134.

Winkler, T., and Buckner, K. (2006), "Receptiveness of Gamers to Embedded Brand Messages in Advergames: Attitude toward Product Placement," Journal of Interactive Advertising. Vol. 7, No. 1, pp. 37-46.

Wise, K., Bolls, P.D., Kim, H., Venkataraman, A., and Meyer, R. (2008), "Enjoyment of Averages and Brand Attitudes: The Impact of Thematic Relevance," Journal of Interactive Advertising, Vol. 9, No. 1, pp. 27-36.

Yang, M.H., Roskos-Ewoldsen, D.R., Dinu, L. and Arpen, L.M. (2006), "The Effectiveness of 'In-Game' Advertising: Comparing College Students' Explicit and Implicit Memory for Brand Names," Journal of Advertising, Vol. 35. No. 4, pp. 143-152.

Zarantonello, L. and Schmitt, B. (November 14. 2012), "The Impact of Event Marketing on Brand Equity: The Mediating Roles of Brand Experience and Brand Attitude," International Journal of Advertising, Forthcoming. Available at SSRN: http://ssm. com/abstract $=2175793$ 